\title{
The Effect of Three Decontamination Methods on COBAS Amplicor Mycobacterium tuberculosis PCR Assay
}

Gülnur Tarhan ${ }^{1 *}$, Mehmet Bakır Saygan ${ }^{2}$, Salih Cesur ${ }^{3}$, Fatih Ocak ${ }^{4}$ and İsmail Ceyhan ${ }^{5}$

${ }^{1}$ Department of Medical Microbiology, Faculty of Medicine, Adıyaman University, Adıyaman, Turkey

${ }^{2}$ National Blood Center, Microbiology Laboratory, Ankara, Turkey

${ }^{3}$ Ankara Training and Research Hospital, Clinic of Infectious Diseases, Ankara, Turkey

${ }^{4}$ Yenimahalle Training and Research Hospital, Microbiology Laboratory, Ankara, Turkey

${ }^{5}$ Atatürk Chest Diseases and Thoracic Surgery Education and Research Hospital, Microbiology Laboratory, Ankara, Turkey

"Corresponding author: Tarhan G, Department of Medical Microbiology, Faculty of Medicine, Adıyaman University, Adıyaman, Turkey, Tel: 905059448568; E-mail: gulnur.tarhan@yahoo.com

Rec Date: Apr 03 2016; Acc Date: Jun 02 2016; Pub Date: June 142016

Copyright: (C) 2016 Tarhan G, et al. This is an open-access article distributed under the terms of the Creative Commons Attribution License, which permits unrestricted use, distribution, and reproduction in any medium, provided the original author and source are credited.

\begin{abstract}
In this study, we evaluated the effect of three decontamination-homogenization-concentration (DHC) methods on COBAS Amplicor Mycobacterium tuberculosis (MTB) PCR system (Roche Diagnostics, Inc., Branchburg, USA) in three different periods. A total of 1210 clinical specimens (602 pulmonary, 608 extrapulmonary specimens) were investigated. Specimens were decontaminated periodically using three $\mathrm{DHC}$ methods (Method A: $3 \% \mathrm{NaOH}-$ trisodium citrate-N-acetyl-L-cysteine (NALC), Method B: $4 \%$ NaOH-Bromothymol Blue (BTB) method-Direct, Method C: $4 \% \mathrm{NaOH}-\mathrm{BTB}$ method-irrigation before DNA extraction method). Definitive results were obtained from 1011 $(83.6 \%)$ of 1210 samples. The inhibition rates according to DHC methods (Method A, B, C) were respectively $3.3 \%$ (10/302), $4.3 \%(7 / 162)$ and $17.3 \%$ (24/138) for pulmonary samples; $10.3 \%(30 / 291), 19.5 \%(33 / 169)$ and $35.1 \%$ $(52 / 148)$ for extrapulmonary samples; $6.7 \%$ (40/593), $12.1 \%(40 / 331)$ and $26.5 \%(76 / 286)$ for all samples respectively When inhibition rates were compared in terms of samples types and numbers, high inhibitor rates were found in urine $24.4 \%$, cerebrospinal fluid (CSF) $9.5 \%$ and gastric lavage fluid (GLF) $7.6 \%$, respectively. Using culture results as standard, the sensitivity, specificity, positive (PPV) and negative (NPV) predictive values of COBAS Amplicor MTB PCR assay were, respectively, $68.2 \%, 99.1 \%, 75 \%$ and $98.8 \%$ for the method A, $66.7 \%, 98 \%, 75 \%$ and $96.9 \%$ for method $\mathrm{B}, 75.0 \%, 98.9 \%, 75 \%$ and $98.8 \%$ for method $\mathrm{C}$.
\end{abstract}

We conclude that laboratories planning to use nucleic acid amplification (NAA) methods as supplement to conventional methods, should be prefer $3 \% \mathrm{NaOH}$-trisodium citrate-NALC method.

Keywords: Tuberculosis; COBAS Amplicor MTB PCR assay; Decontamination methods

\section{Introduction}

Clinical mycobacteriology laboratories play an important role in the control of the spread of tuberculosis through the timely detection, isolation and identification of Mycobacterium tuberculosis complex (MTBC). The principal methods include acid-fast staining, culture of decontaminated samples on solid media or liquid culture and molecular techniques. COBAS Amplicor MTB PCR system is a semiautomated molecular method used especially in the rapid diagnosis of MTBC from pulmonary samples [1]. Its advantages are that it yields results rapidly, all steps of the test are standardized and have internal controls. The manufacturers suggest that COBAS Amplicor MTB sediments of respiratory specimens which have been decontaminated according to the $\mathrm{N}$-acetyl-L-cysteine (NALC)- $\mathrm{NaOH}$ or $\mathrm{NaOH}$ method has been recommended by the Centers for Disease Control and Prevention (Atlanta, Ga.) [2,3]. But, it also has disadvantages such as taking too much time, rapid deterioration and contamination of the solutions used. Therefore, particularly laboratories that has limited financial means and are faced with too many materials prefer $4 \%$ $\mathrm{NaOH}-\mathrm{DHC}$ method that uses Bromothymol blue (BTB) as indicator at the stage of neutralization [4]. The inhibitory effects of bromothymol blue in PCR assays have not been previously reported. The aim of this study was to evaluate the effect of three decontaminationhomogenization-concentration (DHC) methods on COBAS Amplicor MTB system retrospectively.

\section{Materials and Methods}

Patients and clinical specimens: In this retrospective study, a total of 1210 clinical specimens (602 pulmonary, 608 extrapulmonary specimens) that have been evaluated in our laboratory for MTBC testing were evaluated in three different periods. Sputum, gastric lavage fluids, bronchial washings, bronchial lavages and pleural fluids were evaluated as pulmonary specimens, and biopsies, blood, cerebrospinal fluids, aspirates, stool, urine, abscess fluids, sinovial, pericardial fluids, peritoneal fluids (including ascitic fluids) semen fluids and wound swabs as extrapulmonary specimens. Specimens received from contaminated sites were digested and decontaminated periodically using decontamination-homogenization-concentration (DHC) method. Tissues were homogenized by a sterile disposable tissue grinder on the basis of tissue size prior to decontamination and concentration. After concentration, a residual volume of $2-3 \mathrm{ml}$ remained. After preparation of smears, $1 \mathrm{ml}$ was aliquoted for PCR 
testing and stored at $4^{\circ} \mathrm{C}$ until tested. Another $0.5 \mathrm{ml}$ was inoculated onto three separated Löwenstein-Jensen slopes, which were incubated at $37^{\circ} \mathrm{C}$. Slopes were inspected weekly for up to 8 weeks. Fixed smears were stained with Erlich-Zielh-Neelsen staining method.

\section{DHC Methods}

Method A: 3\% NaOH-N-acetyl-L-cysteine (NALC) method: Method A: 3\% NaOH-N-acetyl-L-cysteine (NALC) method

In this method, 593 specimens were decontaminated according to Dio-Safeprocess ${ }^{\otimes}$ decontamination and concentration kit (Diomed, Inc., İstanbul, Turkey). Briefly, each specimen was collected containing NALC and glass beads in a sterile $50 \mathrm{ml}$ conical polypropylene screwcap centrifuge tube and added a volume of $\mathrm{NaOH}$ (final concentration, $3 \%)$ solution equal to the volume of the specimen. The tubes were agitated on a vortex mixer, and kept for $15 \mathrm{~min}$ at room temperature $\left(20^{\circ} \mathrm{C}-25^{\circ} \mathrm{C}\right)$. Each mixture was diluted to the $50 \mathrm{ml}$ mark with sterile $0.067 \mathrm{M}$ phosphate buffer ( $\mathrm{pH}: 6.8$ ). After centrifugation at 4,000Xg for $10 \mathrm{~min}$, supernatant was removed. Each pellet was resuspended in 1.0 $\mathrm{ml}$ sterile $0.067 \mathrm{M}$ phosphate buffer (pH: 6.8).

\section{Method B: 4\% NaOH bromothymol blue (BTB) method: Direct method}

331 specimens were decontaminated by using this method. In brief, equal volume of $4 \% \mathrm{NaOH}$ was added to the sample and vortexed for $10 \mathrm{~s}$. It was kept for $15 \mathrm{~min}$ at room temperature and centrifuged at $10000 \mathrm{Xg}$ for $15 \mathrm{~min}$. Supernatant was removed. 1-2 drops of BTB indicator was dropped on pellet. For neutralization, 1.2-2 N HCl was added to the precipitate drop by drop. After each drop, sediment was slightly shaken and color change was controlled. Acid drop procedure was discontinued at the point yellow color appeared. For neutralization, $4 \% \mathrm{NaOH}$ solution was added slowly until blue color appeared. The remaining precipitate was suspended in distilled water so as to have a final volume of $2 \mathrm{ml}$ [4].

\section{Method C: 4\% $\mathrm{NaOH}$ bromothymol blue (BTB) methods: Irrigation before extraction method}

COBAS Amplicor MTB PCR: 286 specimens were decontaminated by using this method. In this method, samples were processed with method B and were irrigated before PCR test. For this purpose, suspended sample was centrifuged at $10,000 \mathrm{xg}$ for $10 \mathrm{~min}$. After supernatant was removed, $500 \mathrm{ml}$ distilled water was added to the pellet. The same procedure was repeated three times. At the last stage, pellet was suspended with $250 \mu$ sterile distilled water.

Before study, all samples were decontaminated DHC method separately and those belonging to the same patient were united. For PCR amplification, all samples were prepared according to the instructions of the manufacturer. Amplicor Respiratory Specimen Preparation Kit (Roche Diagnostics, Inc., Branchburg, USA) was used for DNA extraction. In brief, $100 \mu$ of sediment was washed in $500 \mu \mathrm{l}$ of Wash Solution. After lysis at $60^{\circ} \mathrm{C}$ for $45 \mathrm{~min}$ in $100 \mu \mathrm{l}$ of Lysis Reagent, the samples were neutralized by addition of $100 \mu \mathrm{l}$ Neutralization Reagent. $50 \mu$ prepared patient specimens and negative and positive controls was transferred to tubes containing the master mix and loaded into the COBAS Amplicor apparatus for the automated amplification and detection process. After hybridization between amplicon and probes specific for MTB and MCC, the amount of hybridization product was measured spectrophotometrically by determining the optical density (OD) value. To OD value ranged between 0.000-3.999, and cut-off value of 0.350 was taken to discriminate between positive and negative results as recommended by manufacturer. Values of 4.000 or more were standardized to 4.000 , because those values exceeded the linear range of the photometer. Inhibited specimens (MTB and MCC, <350 OD) were retested after dilution (1:10) of the samples with sterile distilled water.

Statistical analysis: The sensitivity, specificity, positive predictive value (PPV), and negative predictive value (NPV) of the COBAS Amplicor MTB PCR assay were calculated by contrasting the PCR results with the culture results, which were considered as the reference. Statistical comparison was performed by using Wilcoxon signed rank test.

\section{Results}

Overall 1210 samples (602 pulmonary, 608 extrapulmonary) were processed by three DHC methods and evaluated by COBAS Amplicor MTB PCR assay in three different periods. The distribution and PCR inhibition rates of samples in each DHC method are shown in Table 1.

\begin{tabular}{|c|c|c|c|c|c|c|c|c|}
\hline \multirow[t]{3}{*}{ Type of specimen } & \multicolumn{6}{|c|}{ DHC Methods } & \multicolumn{2}{|c|}{ Total } \\
\hline & \multicolumn{2}{|c|}{$\begin{array}{l}\text { Method A ( } 3 \% \text { NaOH-trisodium } \\
\text { citrat-NALC method) }\end{array}$} & \multicolumn{2}{|c|}{$\begin{array}{l}\text { Method B }(4 \% \text { NaOH BTB- } \\
\text { Direct method) }\end{array}$} & \multicolumn{2}{|c|}{$\begin{array}{l}\text { Method C } \begin{array}{l}(4 \% \\
\text { irrigation }\end{array} \text { before } \\
\text { method })\end{array}$} & \multirow[b]{2}{*}{$\begin{array}{l}\text { No.of } \\
\text { specimens }\end{array}$} & \multirow[b]{2}{*}{$\begin{array}{l}\text { Inhibition } \\
(\%)\end{array}$} \\
\hline & $\begin{array}{ll}\text { No. } & \text { of } \\
\text { specimens }\end{array}$ & $\begin{array}{l}\text { Inhibition } \\
(\%)\end{array}$ & $\begin{array}{l}\text { No. } \\
\text { specimens }\end{array}$ & $\begin{array}{l}\text { Inhibition } \\
(\%)\end{array}$ & $\begin{array}{l}\text { No. of } \\
\text { specimens }\end{array}$ & $\begin{array}{l}\text { Inhibition } \\
(\%)\end{array}$ & & \\
\hline Gastric Lavage Fluid & 210 & $7(3.3)$ & 95 & $5(5.3)$ & 91 & $18(19.8)$ & 396 & $30(7.6)$ \\
\hline Sputum & 58 & $1(1.7)$ & 34 & $1(2.9)$ & 30 & $3(10.0)$ & 122 & $5(4.1)$ \\
\hline $\begin{array}{l}\text { Bronchoalveolar } \\
\text { Lavage Fluid }\end{array}$ & 11 & $1(9.1)$ & 7 & - & 7 & $1\left(^{*}\right)$ & 25 & $2(8.0)$ \\
\hline Pleural Fluid & 23 & $1(4.3)$ & 26 & $1(3.8)$ & 10 & $2(20.0)$ & 59 & $4(6.8)$ \\
\hline Urine & 202 & $24(11.9)$ & 108 & $29(26.9)$ & 87 & $44(50.6)$ & 397 & $97(24.4)$ \\
\hline
\end{tabular}


Citation: Tarhan G, Saygan MB, Cesur S, Ocak F, Ceyhan I (2016) The Effect of Three Decontamination Methods on COBAS Amplicor Mycobacterium tuberculosis PCR Assay. J Med Microb Diagn 5: 231. doi:10.4172/2161-0703.1000231

Page 3 of 5

\begin{tabular}{|c|c|c|c|c|c|c|c|c|}
\hline Cerebrospinal Fluid & 40 & $4(10.0)$ & 18 & - & 26 & $4(15.4)$ & 84 & $8(9.5)$ \\
\hline Peritoneal Fluid & 22 & - & 16 & - & 10 & - & 48 & - \\
\hline Pericardial Fluid & 1 & - & 1 & - & 5 & $1\left(^{*}\right)$ & 7 & $1\left(^{*}\right)$ \\
\hline Synovial Fluid & 6 & - & 3 & - & 9 & - & 18 & - \\
\hline Blood & 3 & - & 1 & - & - & - & 4 & - \\
\hline Aspirate & 3 & - & 4 & - & 1 & - & 8 & - \\
\hline Abscess Fluid & 7 & $1\left(^{*}\right)$ & 4 & $1\left(^{*}\right)$ & 3 & - & 14 & $2(14.3)$ \\
\hline Biopsy & 5 & $1\left(^{*}\right)$ & 11 & $2\left(^{*}\right)$ & 4 & $1\left(^{*}\right)$ & 20 & $4(20.0)$ \\
\hline Stool & - & - & - & - & 1 & $1\left(^{*}\right)$ & 1 & $1\left(^{*}\right)$ \\
\hline Semen Fluid & 1 & - & - & - & 2 & $1\left(^{*}\right)$ & 3 & $1\left(^{*}\right)$ \\
\hline Wound Swab & 1 & - & 3 & $1\left(^{*}\right)$ & - & - & 4 & $1\left(^{*}\right)$ \\
\hline Total & 593 & $40(6.7)$ & 331 & 40 (12.1) & 286 & 76 (26.5) & 1210 & $156(12.8)$ \\
\hline
\end{tabular}

Table 1: Distribution of samples according to DHC ( Decontamination-Homogenization and Concentration) and inhibition rates in COBAS Amplicor MTB PCR assay.

The inhibition rates according to DHC methods (Method A, B, C) were respectively $3.3 \%(10 / 302), 4.3 \%(7 / 162)$ and $17.3 \%(24 / 138)$ for pulmonary samples; $10.3 \%(30 / 291), 19.5 \%(33 / 169)$ and $35.1 \%$ (52/148) for extrapulmonary samples; 6.7\% (40/593), 12.1\% (40/331) and $26.5 \%(76 / 286)$ for all samples respectively. In overall evaluation, the inhibition rates were $6.8 \%(41 / 602), 18.9 \%(115 / 608)$ and $12.8 \%$ $(156 / 1210)$ for pulmonary, extra pulmonary and all samples respectively.
Definitive results were obtained in 1011 (83.6\%) of 1210 samples in the first study. In $156(12.8 \%)$, the presence of inhibitor and in 43 (3.6\%) positivity was detected (Table 2 ). After main suspensions of samples in which inhibitor was detected were diluted with distilled water at 1/10 ratio, PCR test was repeated at the same standards. In 156 samples, definitive results were obtained in 135 (86.5\%). The remaining 21 samples were not evaluated as inhibition was detected again.

\begin{tabular}{|c|c|c|c|c|}
\hline & \multicolumn{4}{|c|}{ DHC Methods } \\
\hline & $\begin{array}{l}\text { Method A ( } 3 \% \mathrm{NaOH} \text {-trisodium citrate- } \\
\text { NALC method) }\end{array}$ & $\begin{array}{l}\text { Method B } \quad(4 \\
\text { method) }\end{array}$ & $\mathrm{NaOH}$ BTB-Direct & $\begin{array}{l}\text { Method } \mathrm{C} \quad(4 \% \mathrm{NaOH} \text { BTB-irrigation } \\
\text { before extraction method })\end{array}$ \\
\hline Culture negative PCR negative & 565 & & 288 & 261 \\
\hline Culture negative PCR positive & 5 & & 6 & 3 \\
\hline Culture positive PCR negative & 7 & & 9 & 3 \\
\hline Culture positive PCR positive & 15 & & 18 & 9 \\
\hline Total & 592 & & 321 & 276 \\
\hline$\%$ Sensitivity & 68.2 & & 66.7 & 75.0 \\
\hline$\%$ Specificity & 99.1 & & 98.0 & 98.9 \\
\hline$\%$ PPV & 75.0 & & 75.0 & 75.0 \\
\hline$\%$ NPV & 98.8 & & 96.9 & 98.8 \\
\hline
\end{tabular}

Table 2: Comparison of culture results and COBAS Amplicor MTB PCR assay according to DHC methods.

The sensitivity, specificity, positive predictive values (PPV) and negative predictive values (NPV) of COBAS Amplicor MTB PCR assay in samples processed with three DHC methods are outlined in Table 2.
These values were respectively, $68.2 \%, 99.1 \%, 75.0 \%, 98.8 \%$ for method A, $66.7 \%, 98.0 \%, 75.0 \%, 96.9 \%$ for method B, and 75.0\%, 98.9\%, $75.0 \%$ and $98.8 \%$ for method C. 


\section{Discussion}

At present, the diagnosis of tuberculosis is made based on symptoms, clinical and radiological findings and tuberculin skin test, but for definitive diagnosis, the direct demonstration of MTB in secretion, body fluids and tissue or its growth in the cultures prepared from these samples is required. Conventional culture method is considered the gold standard for the identification of MTBC in clinical samples. But, for precise diagnosis on incubation period lasting 6-8 weeks is required [5,6]. Therefore, rapid and reliable tests that will make rapid diagnosis possible are warranted. This period has been further shortened by means of recent nucleic acid amplification (NAA) methods and rapid culture systems. It has been possible to identify the agent in 1-2 days, using NAA methods. In practice of different laboratories, the mean sensitivity and specificity of these methods were found to be $82 \%$ and $99 \%$ among these, COBAS Amplicor MTB PCR assay, has been used commonly in routine diagnosis [6-9]. In various laboratories where this test is employed, MTBC has been identified with high specificity in respiratory samples, smear positive extrapulmonary samples and BACTEC 12 B culture systems [10]. The most important advantage of Cobas Amplicor MTB assay are that all steps are carried out according to standard protocols, internal control systems are present for each test and it does not require extra procedure during MTBC evaluation. It has been suggested that the test may be inhibited due to metabolic products in clinical specimens such as bile salts, bilirubin and polysaccharides and inhibitor substances that may exist in work environment during manual extraction procedure. Reischl et al. reported that in 1149 respiratory and nonrespiratory samples, inhibition rate was found to be lower than $2 \%$ in all samples other than stool samples. They have stated that low rates may be related to standard DHC method and suggested that, especially in samples with excessive inhibition (such as stool), inhibitors may be removed during extraction procedure by the use of methods such as solvent extraction, protein salting-out and solid-phase DNA binding methods. In studies conducted to date, no standard extraction method has been defined for removing inhibitors from clinical samples. However, it has been proposed that with extraction procedures where silica membranes are utilized this probability may be decreased.

Böddinghaus et al. investigated PCR inhibitor efficacy in 665 pulmonary and extrapulmonary samples evaluated with COBAS Amplicor MTB PCR assay in a prospective study and extracts belonging to samples with inhibition were extracted a second time with silica membrane protocol. They reported that inhibition rate was reduced from $12.5 \%-1.1 \%$ with this procedure. In this study, higher rates of inhibition were found in extrapulmonary samples (18.6\%), compared to pulmonary samples, with highest inhibition rates in lymph node biopsy samples (51\%). In our study, 1210 samples (602 pulmonary, 608 extrapulmonary) were evaluated according to standard procedure by COBAS Amplicor MTB PCR assay after undergoing three DHC methods periodically. The inhibition rates of samples in each DHC method are outlined in Table 1. When inhibition rates were compared in terms of samples types and numbers, highest inhibitor presence was detected in GLF (7.6\%) among pulmonary samples, and in urine (24.4\%) and CSF (9.5\%) among extrapulmonary samples (Table 1).

As stated above, the lowest inhibition rates were observed with Method A recommended by the manufacturer. It was thought that higher rates of inhibition found in methods B and C should be attributed to use of BTB as an indicator in these methods rather than the type of samples. Especially in Method C with highest rate of inhibition despite irrigation procedure before PCR, it was observed that inhibitor substances (BTB and other substances added) could not be removed.

21 samples in which inhibition was detected in both studies $(1,10$ and 10 respectively for methods $\mathrm{A}, \mathrm{B}$ and $\mathrm{C}$ ), were excluded from evaluation. Sensitivity, specificity, PPV and NPV of the samples processed with three DHC methods are summarized in Table 2. These values were respectively, $68.2 \%, 99.1 \%, 75.0 \%, 98.8 \%$ for method $\mathrm{A}$, $66.7 \%, 98.0 \%, 75.0 \%, 96.9 \%$ for method $\mathrm{B}$, and $75.0 \%, 98.9 \%, 75.0 \%$ and $98.8 \%$ for method C.

The sensitivity of COBAS Amplicor MTB PCR assay was between $60.2-96.0 \%$ and, specificity was over $96 \%$ in in studies using $3 \%$ $\mathrm{NaOH}$-trisodium citrate-NALC DHC method [11-15].

D'amato et al. reported the sensitivity, specificity, PPV and NPV rates to be $66.7 \%, 99.6 \%, 91.7 \%$ and $97.7 \%$ respectively in their study with 985 pulmonary samples. Resichl et al. examined 643 pulmonary samples (irrespective of microscopy), and found these rates to be $84.2 \%, 99.1 \%, 90.6 \%$ and $98.5 \%$ in pulmonary samples; $71.8 \%, 98.1 \%$, $75.7 \%$ and $97.7 \%$ in extrapulmonary samples and $83.5 \%, 99.8 \%, 86.7 \%$ and $98.6 \%$ in all samples. Our results with the DHC method are consistent with other studies. To our knowledge, there are no other studies reporting results on the other DHC methods we used.

In our study, we detected culture positive and PCR negative results. It rates according to DHC methods (Method A, B and C) were respectively $1.18 \%$ (7/592), 2.80\% (9/321) and 1.09\% (3/276). Negative results obtained by amplification assays for culture-positive samples are usually explained by the presence of inhibitors of enzymatic amplification, a low number of mycobacteria, and/or an unequal distribution in the test suspension. The inhibition rates according to DHC methods (Method A, B, C) were respectively 3.3\% (10/302), 4.3\% (7/162) and $17.3 \%(24 / 138)$ for pulmonary samples; $10.3 \%(30 / 291)$, $19.5 \%(33 / 169)$ and $35.1 \%(52 / 148)$ for extrapulmonary samples; $6.7 \%$ (40/593), $12.1 \%(40 / 331)$ and $26.5 \%(76 / 286)$ for all samples respectively. DHC method employing BTB is used in Turkey especially in laboratories with limited means. Yet, although this method is advantageous for rapid diagnosis of MTBC, it causes high rates of inhibition in NAA tests, and this inhibitor effect could not be removed even with active irrigation. In conclusion, COBAS Amplicor MTB PCR assay is an automated, reliable and rapid method for pulmonary samples and extrapulmonary samples in that it detects presence inhibitor due to internal control. Nevertheless, in cases positive results are not comparable with microscopy and clinical findings. Positive results should be corroborated with the same test or a different NAA method.

\section{References}

1. Reischl U, Lehn N, Wolf H, Naumann L (1998) Clinical evaluation of the automated COBAS AMPLICOR MTB assay for testing respiratory and nonrespiratory specimens. J Clin Microbiol 36: 2853-2860.

2. (2009) Updated Guidelines for the Use of Nucleic Acid Amplification Tests in the Diagnosis of Tuberculosis. MMWR 58: 7-10.

3. Kubica GPW, Dye E, Cohn ML, Middlebrook G (1963) Sputum digestion and decontamination with $\mathrm{N}$-acetyl-L-cysteine-sodiumhydroxide for culture of mycobacteria. Am Rev Respir Dis 87: 775-780.

4. Gumuşlu F, Ceyhan I, Kocagöz T, Sönmez N (1998) Tüberküloz Laboratuvar Rehberi. Published by Ministery of Healt Refik Saydam Hygiene Center,Ankara, Turkey.

5. Nolte FS, Metchock B (1995) Mycobacterium. In: Murray PR, Baron EJ, Pfaller MA, Tenover FC, Yolken RH (Eds). Manual of clinical 
Citation: Tarhan G, Saygan MB, Cesur S, Ocak F, Ceyhan I (2016) The Effect of Three Decontamination Methods on COBAS Amplicor Mycobacterium tuberculosis PCR Assay. J Med Microb Diagn 5: 231. doi:10.4172/2161-0703.1000231

Page 5 of 5

microbiology, (6thedn), American Society for Microbiology, Washington, D.C.

6. Runyon EH, Karlson AG, Kubica GP, Wayne LG (1980) Mycobacterium. In: Lennette EH, Balows A, Hausler WJ Jr, Truant JP (Eds). (3rdedn), Manual of clinical microbiology, American Society for Microbiology, Washington, D.C

7. Vlaspolder F, Singer P, Roggeveen C (1995) Diagnostic value of an amplification method (Gen-Probe) compared with that of culture for diagnosis of tuberculosis. J Clin Microbiol 33: 2699-2703.

8. Schirm J, Oostendorp LAB, Mulder JG (1995) Comparison of AMPLICOR, in-house PCR, and conventional culture for detection of Mycobacterium tuberculosis in clinical samples. J Clin Microbiol 33: 3221-3224.

9. Wobeser WL, Krajden M, Conly J, Simpson H, Yim B, et al. (1996) Evaluation of Roche Amplicor PCR assay for Mycobacterium tuberculosis. J Clin Microbiol 34: 134-139.

10. Ninet B, Rochner P, Metral C, Auckenthaler R (1999) Assessment of use of the COBAS AMPLICOR system with BACTEC 12B cultures for rapid detection of frequently identified mycobacteria. J Clin Microbiol 37: 782-784.
11. Böddinghaus BTA, Wihchelhaus TA, Brade V, Bittner T (2001) Removal of PCR inhibitors by silica membranes: Evaluating the Amplicor Mycobacterium tuberculosis. Kit J Clin Microbiol 39: 3750-3752.

12. D'Amato RF, Wallmann AA, Hochstein LH, Colaninno PM, M Scardamaglia, et al. (1995) Rapid diagnosis of pulmonary tuberculosis by using Roche AMPLICOR Mycobacterium tuberculosis PCR test. J Clin Microbiol 31:1832-1834.

13. Peter-Getzlaff S, Lüthy J, Böddinghaus B, Böttger EC, Springer B (2008) Development and evaluation of a molecular assay for detection of nontuberculous mycobacteria by use of the Cobas Amplicor platform. J Clin Microbiol.46: 4023-4028.

14. Piersimoni C, Scarparo C (2003) Relevance of commercial amplification methods for direct detection of Mycobacterium tuberculosis complex in clinical samples. J Clin Microbiol 41: 5355-5365.

15. Peter-Getzlaff S, Lüthy J, Voit A, Bloemberg GV, Böttger EC (2010) Detection and identification of Mycobacterium spp. in clinical specimens by combining Roche Cobas Amplicor Mycobacterium tuberculosis assay with Mycobacterium genus detection and nucleic acid sequencing. J Clin Microbiol 48: 3943-3948. 